Corporate Social Responsibility (CSR) Activities and Stakeholder

Perception: A Case Study on a CSR Project of a Multinational

Corporation in Sri Lanka

\begin{abstract}
$\forall A$
Samarakoon Mudiyanselage Gayani Priyankara Kumari

Samarakoon
\end{abstract}

A thesis ssubmitted to the Univiversity off SSii J Jayeawandenepura in partial fulfillmentt of the requirementts for the Degree of Master of Science in Management on $31^{\text {st }}$ January 2014. 
The work described in this thesis was carried out by me under the supervision of Dr.(Mrs). B.J.H. Arachchige and a report on this has not been submitted in whole or in part to any university or any other institution for another Degree/ Diploma.

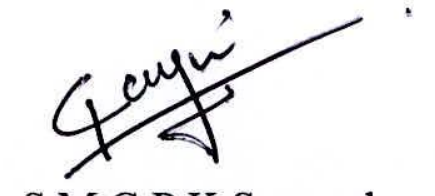

S.M.G.P.K.Samarakoon 
I certify that the above statement made by the candidate is true and that this thesis is suitable for submission to the University for the purpose of evaluation.

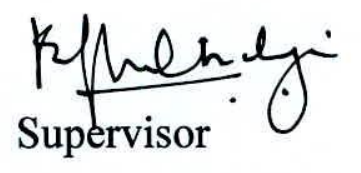

Dr. (Mrs.) B.J.H. Arachchige

Senior Lecturer

Department of Human Resource Management

Faculty of Management Studies and Commerce

University of Sri Jayewardenepura 


\section{Table of Contents}

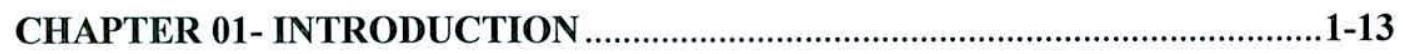

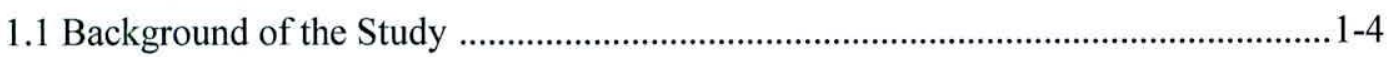

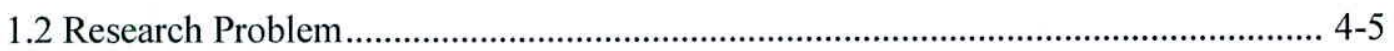

1.3 Objectives of the Study

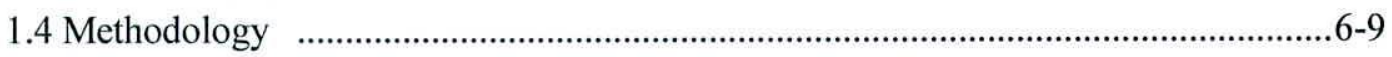

1.5 Significance of the Study ................................................................................... $9-10$

1.6 Scope and Limitations ………………............................................................11-12

1.7 Chapter Organization ..........................................................................................12-13

CHAPTER 02- LITERATURE REVIEW ………............................................14-56

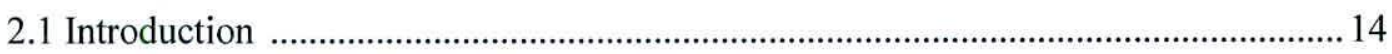

2.2. Corporate Social Responsibility: An Overview ................................................... 14-20

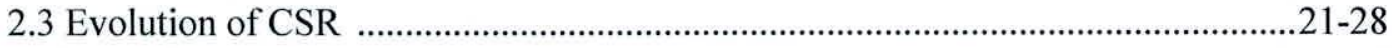

2.4 What does CSR Mean? ……...........................................................................28-32

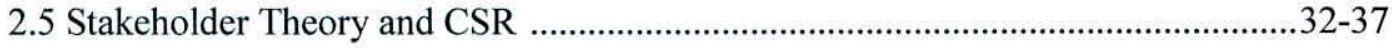

2.6 Why Organisations [including MNCs] Concern on CSR? ...................................37-41

2.6.1 Pressures on MNCs .......................................................................................

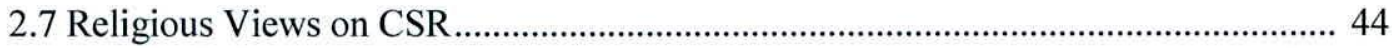

2.7.1 Social Responsibility in Buddhist Philosophy ..............................................45-47

2.7.2 CSR from Islamic Perspective ......................................................................47-51

2.8 CSR in Sri Lankan Context ..............................................................................51-56

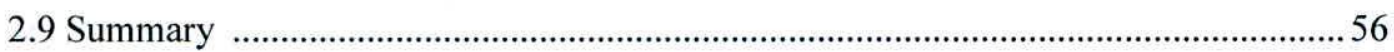




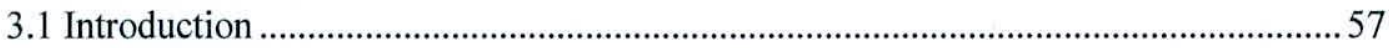

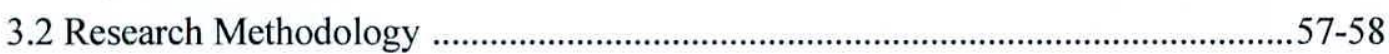

3.2.1 Why Qualitative Case Study Method? ........................................................... 58-60

3.2.1.1 Justification for choosing single case study method ..............................60-62

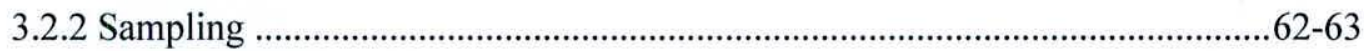

3.2.3 Sources used for data collection........................................................................... 64

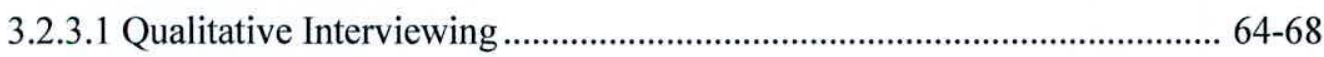

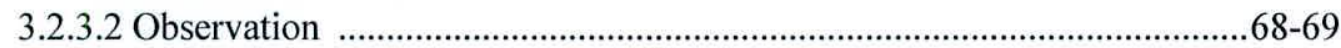

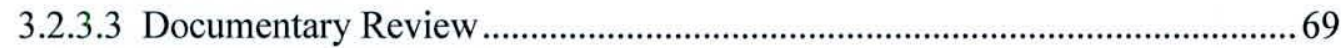

3.2.4 Data Analysis and Interpretation....................................................................

3.3 Research Reliability \& Validity ........................................................................ 73-74

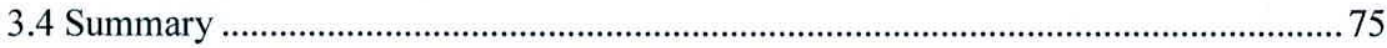

CHAPTER 04 - DATA PRESENTATION AND ANALYSIS ............................76-104

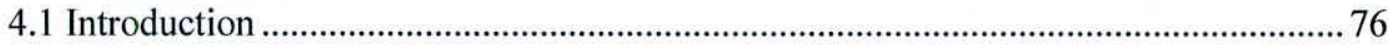

4.2 The Company - 'OneHeart' and its CSR Framework .............................................76-78

4.3 Why Does 'OneHeart' Contribute to CSR …….....................................................78-85

4.4 The Wells Renovation Project......................................................................... 85-89

4.5 Socio - Economic Background of the Targeted Community.....................................89-91

4.5.1. Unmet Needs and Wants of the Targeted Community ....................................91-93

4.5.2 The problem of water ………...................................................................93-97

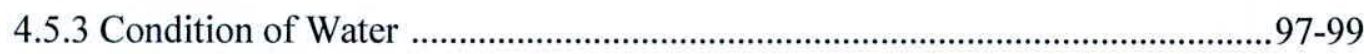

4.6 Perception of the Affected People .......................................................................99-103

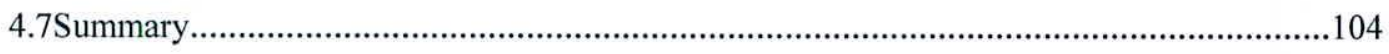




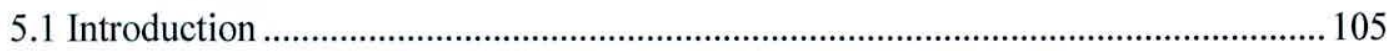

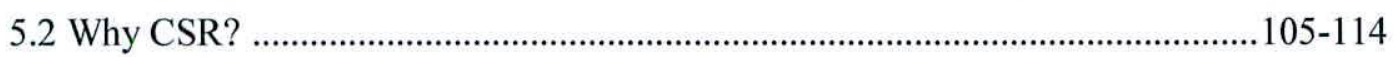

5.3 How Do People Perceive? ............................................................................114-117

5.6 Implications of the Study ............................................................................117-118

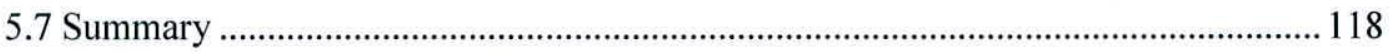

CHAPTER 06 - SUMMERY AND CONCLUSION ..........................................119-123

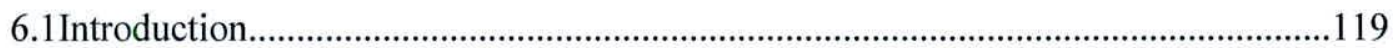

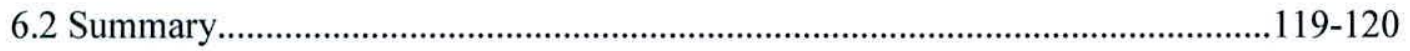

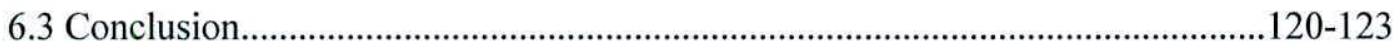

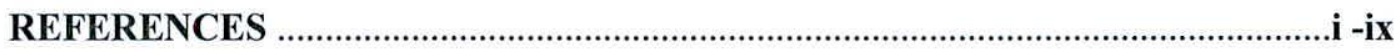

APPENDICES

Appendix 1- Interview Schedules .........................................................................xi-xiii

1.(a).Interview Schedules for the affected community ............................................... xi

(b). Interview schedules for company managers ...................................................xii

(c) Interview schedules for Grama Niladari Officers ............................................iii

Appendix2- Observation Guide.....................................................................................

Appendix 03- Details of the interview participants interviewed ..................................

Appendix 04 -(a). The climate of the villages........................................................................

(b).Condition of the houses of the villagers................................................ix

(c).Current condition of the wells ............................................................... 


\section{List of table}

Table

Page No.

Table 1: Spectrum of viewpoints on the role of business in society 36

Table 2: Islamic Perspectives on CSR Practices $50-51$

Table 3: Unit of analysis 62

Table 4: Contents of Water..... 98 


\section{Acknowledgement}

First of all, I would like to give my heartiest gratitude to my research supervisor, Dr.(Mrs). B.J.H. Arachchige for her enormous guidance and encouragement given to me. I highly appreciate the continuous supervision and direction that she provided throughout the study. Secondly, I would like to express my thanks to all the participants in the study for their great support. Without their honest support, I may not have been able to complete this study successfully. Finally, I would like to extend my gratitude to my family members and all the other parties/friends who gave their fullest support and encouragement to complete this report successfully. I may not have been able to complete this thesis successfully without the support of any of the parties mentioned above.

S.M.G.P.K.Samarakoon 


\title{
CSR Activities and Stakeholder Perception: A Case Study on a CSR Project of a Multinational Corporation in Sri Lanka
}

\author{
S.M.G.P.K.Samarakoon
}

\begin{abstract}
The main focus of this study is to investigate the involvement of community oriented CSR (Corporate Social responsibility) by the local subsidiaries of multinational companies in Sri Lanka and the targeted community perceptions. This study has been carried out with special reference to the community oriented CSR project implemented by a local subsidiary of a multinational company in Sri Lanka. Business organisations involve in CSR for varying purposes. Some organisations spend on CSR for long term survival and prosperity of the company whereas some are contributing with the sincere purpose of meeting the expectations of multiple stakeholders. On the other hand, a majority of Sri Lankans perceive that the Sri Lankan private sector organisations behave in a socially responsible manner by looking at the externally focused CSR initiatives of the companies and the influence of media. Thus, the objectives of this study are to find the reasons for the CSR involvements aimed at community welfare by a subsidiary of a multinational company in Sri Lanka and to understand the targeted community's perception regarding the CSR project carried out by this multinational corporation. The qualitative approach was used as the main research method and the qualitative case study method was used as the main research strategy. For the purpose of data collection, interviews, observations and documentary reviewing were used. In data analysis, data were categorized into several topics based on the similarity of the data gathered. The findings reflect that the targeted community perceives that the renovation of wells project is just a gesture of good work,
\end{abstract}


but it brings fewer benefits to them. It is concluded that the main purpose of the CSR project, providing access to clean water, has not been archived. This study shows that the company could have done a successful CSR project if the company had conducted a proper needs analysis, as these people have many primary needs to be fulfilled. The company purposes of spending money on community oriented CSR initiative are to enhance the brand image and the corporate reputation while doing some good to the society. This study shows that, if these objectives to be achieved, the company should design the CSR activities properly. 


\section{CHAPTER 1}

\section{INTRODUCTION}

\subsection{Background of the Study}

The world's biggest dairy product exporter, Fonterra, a big multinational company in New Zealand was banned in mid 2013 in some Asian countries due to the fact that some of their products were affected by bacteria and it created a considerably negative impact on the people who consumed those products. This is only one incident that happened recently which reflects the irresponsible behaviour of business organisations in the contemporary business world. However, on the other hand, companies are largely canvassing to convince that they are good corporate citizens who meet the needs of multiple stakeholders including the community at large. For example, Procter \& Gamble, a giant multinational company with the credo of "business with people", always demonstrated its commitment to the community not just through the quality of products and services, but through socially responsible initiatives of the company as well. Apparently, it is the emergence of largescale business organizations in the last third of the nineteenth century both within Europe and the United States that gave rise to concerns about 'Corporate Social Responsibility' (Epstein,2006).

Contemporary business organisations perceive Corporate Social Responsibility (CSR) as something more than just doing good to the wider society since it enhances the corporate position through brand building. Thus, it says that today CSR is considered the root of 
competitive advantages or a factor which greatly affects the company's positive performance (Gupta, 2011,Porter and Krama,2006) and it enables organisations to manage the negative responses of multiple stakeholders (Gupta, 2011). However, the dangerous aspect of this brand building CSR is that organisations may tend to boost their wealth at the expense of deceiving the society that they are good corporate citizens. As such, this study gives special emphasis to multinational corporations and their community oriented CSR activities in Sri Lanka.

Increasing attention has been paid to the concept of Corporate Social Responsibility (CSR) during the last five decades, eventhough the literature reveals that the concept was founded over several decades (Thomas and Nowak, 2006). At present business organisations confront severe competition due to the factors of globalization, and advancement of technology, particularly information technology, and changes that take place in the broad economic and political environment. Because of these reasons, organisations find new ways to defeat their competitors and CSR has become one of them. Increasingly reported socially irresponsible behaviours of organisations and some global environmental changes like global warming and sea level rising [it was recognized that these are the consequences of socially irresponsible behaviours] also have made a strong influence on organisations to behave in a socially responsible manner. Moreover, companies who behaved in a socially responsible way have enjoyed the greater success than those who did not.

Different people perceive the concept of CSR from different perspectives. Some think CSR is just a way to spend on philanthropic activities whereas some perceive CSR as giving equal priority to the economic, social and environmental aspects of the business. However, 
as mentioned by Branco and Rodrigues (2007), Milton Friedman brings an opposing idea to this; CSR of an organisation is to maximize the wealth of the shareholders while complying with the laws given. Hence, organisational resources are provided by the owners and therefore, the organization's responsibility is to earn a return on them as much as possible. Moir (2001) elaborates this thought further,

Those who adopt the neo-classical view of the firm would believe that the only responsibilities to be adopted by business are the provision of employment and payment of taxes. This view is most famously taken to the extremes of maximizing share holder value and reflected in the views of Milton Friedman (p.17).

Freeman (1984) provides a different view than that of Milton Friedmen. According to Freeman, organisations have an obligation to consider several other parties who are affected by thier activities possibly equally with shareholders and these affected parties are identified as stakeholders of the organisation. Further, Holmes (1976) brings another view to Milton Friedmen and Freeman, that is, organisations must voluntarily help to solve social problems whether or not business helps to create problems and even if there is no any short term or long term return. Further, according to Moir (2001), organisations undertake CSR initiatives with enlightened self-interest of business, that is to have a long term return. Further, Gupta (2011) has stated that survival and success of an organisation is contingent upon the satisfying the multiple objectives of various stakeholders. In this context, stakeholder theory conveys the same meaning that is conveyed by the idea of enlightened self-interest.

Under this complex condition, it is difficult to understand the actual purpose of engaging in CSR by business organisations. Contemporary business organisations use very artistic and attractive themes, business policies and purposes which imply their socially responsible 
expectations, and they allocate a considerable amount of funds for their CSR projects annually. Further, today businesses set social goals in addition to the economic goals and keep space for social performance in their annual reports. Moreover, current businesses give massive publicity for their CSR initiatives and make the general public aware about their social commitments.

With special reference to Sri Lankan business organisations, as explained by Rathnasiri (2003), Khan and Beddewella (2008), a majority of Sri Lankan private sector organisations [including multinational corporations] engages in CSR activities at the point of externally focused (popular visible) level rather at the internal policy level and most of the organisations ignore the broad meaning of CSR since their understanding of CSR is related to sponsorship of community activities and donations to good causes (Khan and Beddewella,2008). On the other hand, many of Sri Lankans perceive CSR as that of a corporation from the perspective of philanthropy and they have the idea that private sector organisations are truly socially responsible since they engage in many philanthropic activities viz. donations and sponsorships (Rathnasiri, 2003).

\subsection{Research Problem}

As stated above, business organisations both local and global, involve in CSR initiatives with a variety of purposes viz. enhancing the long term sustainability of their profits, voluntarily helping to solve social problems or uplifting the wellbeing of multiple stakeholders, including the community at large, or a combination of all these. Specially, most of the organisations spend large amounts on CSR, particularly on community oriented 
projects, for the sake of earning publicity rather than truly helping the target community. Therefore, it is very difficult to understand the real motives of the companies engaging in CSR.

Accordingly, I have formulated the problem of the study as a puzzle which will give a clear focus on this study. The problem statement of the study is "Although MNCs spend massively on CSR activities aimed at community welfare, does it aspire only to enhance the welfare of relevant social actors?" Based on the problem statement of the study, I have derived two research questions as follows.

\section{Research Questions}

1. Why does a local subsidiary of an MNC engage in CSR activities within the region of Sri Lanka?

2. How does the targeted community perceive the outcomes of a CSR activity implemented by the above subsidiary within the region of Sri Lanka?

The entire research will be unfolded based on the above mentioned research questions and the research will be concluded providing the answers for the research questions formulated.

\subsection{Objectives of the Study}

Based on the research questions of the study, I have developed two research objectives, which will limit the scope of the study. Research objectives and research questions of a study help researchers to determine the most appropriate data collection and analysis techniques to the study. Research objectives of this study are given below. 